\title{
Ozon tedavisi
}

\author{
Ozone therapy \\ Serdar Kesikburun, Evren Yaşar \\ Sağlık Bilimleri Üniversitesi, Gülhane Tıp Fakültesi, Fiziksel Tıp ve Rehabilitasyon Anabilim Dalı, Ankara
}

\begin{abstract}
Sağlık Bakanlığı Geleneksel ve Tamamlayıcı Tıp Uygulamaları Yönetmeliği ile sertifikalı hekimlerce yapabilmesinin yolu açılan ozon uygulamasının belki de en sık kullanım alanı kas iskelet sistemidir. Kullanılan gaz bileşiğinin \%5 kadarını ozon, geri kalanını oksijen gazı oluşturur. Akut oksidatif stres oluşturduğu için, bir çeşit aşılama yöntemi olduğu da varsayılabilir. Bu yöntemin genel olarak, doğal anti-oksidan sistem, metabolik enzim ve hormon regülasyonu, koagülasyon, oksijenizasyon ve dolaşım düzeni, immün sistem, hücre rejenerasyonu üzerine etkileri olduğu düşünülmektedir. Tıbbi literatürde ozon tedavisi ile ilgili yayınlar son yıllarda artsa da halen kısıtlı sayıdadır. Tıbbi ozon tedavisinde esas hedeflere, doktorun doğru uygulama yöntemi ve hastaya uygun doz belirlenmesi ile ulaşılabilir. Bu bölümde, kas iskelet sistemi ağrılarında tıbbi ozon kullanımının temel prensipleri ele alınmaya çalışılmıştır.
\end{abstract}

Anahtar sözcükler: tıbbi ozon; kas iskelet sistemi
Ozone application that can be used by the physicians after publishing of the Ministry of Health Traditional and Complementary Medicine Regulations may have the most common area of use in musculoskeletal conditions. The mixture of gas includes $5 \%$ ozone and the rest is oxygen. It can be regarded as a vaccination due to its effect of triggering an acute oxidative stress. It is generally considered to have effects on natural anti-oxidant system, regulation of metabolic enzymes and hormones, immune system, and cell regeneration. There are limited publications on ozone therapy in medical literature; even if it has shown an increase in recent years. The effectiveness of ozone therapy depends on accurate application technique and dose decided by the physician. This paper is dealing with basic principles of using medical ozone therapy in painful musculoskeletal conditions.

Key words: medical ozone; musculoskeletal system ki yüz yıl kadar önce keşfi yapılan, en fazla atmosferin stratosfer tabakasında olduğu ve zararlı ultraviyole ışınları önlediği keşfedilen ozon, tek doğal dezenfektan olarak tanımlanmıştır. Bazı Avrupa ülkelerinde sadece içme suyunun temizlenmesinde kullanılan ozonun tedavide kullanımı, uzun süre Almanya, İtalya, Rusya ve Küba ile sınırlı kalmıştır.

2010 yılında İspanya'da yapılan uluslararası bir toplantı sonucunda "Ozon Tedavisinde Madrid Deklarasyonu" yayımlanmıştır. Bu deklarasyonda; ozon tedavisinde terapötik gerekçe, temel ilkeler, önerilen ve önerilmeyen uygulama yöntemleri, hayvan çaIışmalarında uygulamalar, endikasyonlar ve tedavinin genel zemini konularında öneriler ortaya konmuştur. O yıldan beri yıllık toplantılar düzenleyen Uluslararası
Ozon Birliği'nin iki ayda bir yayımlanan bir dergisi de (Ozone) bulunup, 2012 yilında tedavi rehberleri ve stratejileri yayımlanmıştır. ${ }^{[1]}$

Bununla birlikte, 2014 yılında Resmi Gazetede yayımlanarak yürürlüğe giren Sağlık Bakanlığı Geleneksel ve Tamamlayıcı Tıp Uygulamaları Yönetmeliği ile, ozon uygulamasının sertifikalı hekimlerce yapabilmesinin yolu açılmıştır. Bu yönetmeliğe göre, bir ozon jeneratörü ve sensörü aracılığı ile, ozon-oksijen karışımının sistemik veya lokal uygulaması yapılabilmektedir. Tanımlanan endikasyonların çoğu kas-iskelet sistemi patolojilerine aittir (Tablo 1). Bununla birlikte, bu patolojilerin insanlar arasında sık görülmesi, günlük yaşamı etkilemesi ve sıklıkla kronikleşmesi gibi nedenlerle, bu tedavi yöntemi kısa sürede kendine yer bulmuştur.

- İletişim adresi: Doç. Dr. Evren Yaşar, Sağlık Bilimleri Üniversitesi, Gaziler FTR Eğitim ve Araştırma Hastanesi, Bilkent, Ankara Tel: 0312 - 2911407 e-posta: evrenyasar@yahoo.com

- Geliş tarihi: 20 Mart $2017 \quad$ Kabul tarihi: 20 Mart 2017 
Tablo 1. Ozon tedavisi endikasyonları

\author{
Osteoartrit, osteomiyelit ve kemik nekrozu \\ Tendon ve bağ yaralanmaları \\ Miyofasyal ağrı sendromu, fibromiyalji \\ Vertebra ve disk patolojileri \\ Nöropatik ağrı \\ Kronik iyileşmeyen iskemik ve diyabetik yaralar \\ Bası yarası \\ Gingivit, periodontitis \\ Alopesi, dermatit \\ Otit, sinüzit
}

\section{ETKI MEKANIZMASI}

Tıbbi ozon, saf oksijen jeneratör yardımı ile yüksek elektrik voltajıyla etkileştirilerek elde edilir (Şekil 1). Elde edilen gaz bileşiğinin \%5 kadarını ozon, geri kalanını oksijen oluşturur. Su, bitkisel yağ ve plazma, serum fizyolojik (SF) ve oksijen içinde çözünebilir. Ozon, üç atomlu ve oksijene göre daha kararsız bir moleküldür. Bu nedenle, biyolojik cevap oluşturmada oksijene göre daha etkilidir. Güçlü oksidan özelliği ile, okside olabilen tüm organik bileşiklerle kimyasal reaksiyona girebilir. Dezenfekte edici etkisi, güçlü okside edici özelliğindendir. Bu reaksiyon sonucunda, gaz halindeki ozon hızla oksijenden ayrılır ve ozonoid denilen molekülleri oluşturur. ${ }^{[2]}$ Bu çok hızlı gerçekleşir ve artık gaz halinde değildir. Peroksidasyon yoluyla oluşan ozonoid peroksidler başlıca, serbest oksijen türevleri (ROS) ve lipid peroksidasyon türevleri (LOPs) olarak ayrılır. ROS, ozonun erken dönem etkilerinden sorumlu olup hızla doğal anti-oksidan sistem tarafindan nötralize edilir. LOPs, geç etkilerden sorumludur. Akut oksidatif stres oluşturduğu için bir çeşit aşılama yöntemi olduğu da varsayılabilir. Çünkü, her insanın anti-oksidan kapasitesi çeşitli maruziyetlere bağlı olarak farklıdır ve bu maruziyetler arttıkça anti-oksidan kapasite de azalarak çeşitli patolojiler kronisite kazanır. Ancak uygun dozlama ile, burada oluşturulacak stres hasara neden olacak kadar çok olmamalıdır. Genel olarak doğal anti-oksidan sistemin, metabolik enzim ve hormon regülasyonu, koagülasyon, oksijenizasyon ve dolaşım düzeni, immün sistem, hücre rejenerasyonu üzerine etkileri olduğu düşünülmektedir. ${ }^{[2,3]}$ Kas iskelet sistemi özelinde etkileri ise Tablo 2'de özetlenmiştir.

\section{UYGULAMA YOLLARI}

Ozon tedavisinde hem parenteral (intravenöz, intraarteriyel, intramusküler, subkutanöz, intra-artiküler ve

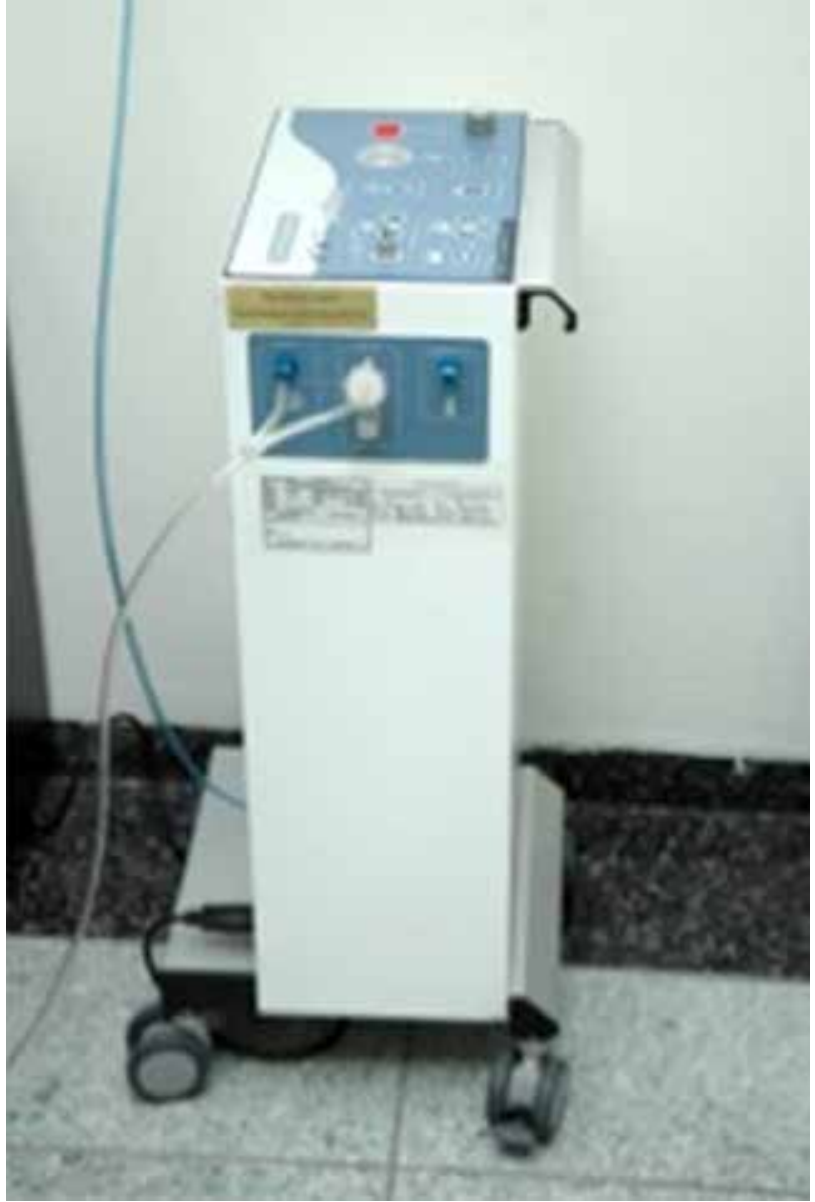

Şekil 1. Ozon jeneratörü.

intraplevral) hem de lokal (nazal, oral, intradiskal, vajinal, kolorektal ve kutanöz) yollar kullanılabilir. ${ }^{[4]}$ Temel uygulama teknikleri Tablo 3'te sıralanmıştır.

En ciddi yan etki olarak akciğer embolizasyonu bildirilmiş olup, çoğu ülkede damar içi direkt uygulamaları yasaklanmıştır. Asepsi kurallarına dikkat edilmeli, doz ve uygulama yollarında uygun seçimler yapılmalıdır. Genel olarak; glukoz-6-fosfat-dehidrogenaz enzim eksikliği olanlar, gebeler, anjiyotensin çevirici enzim inhibitörü tedavisi görenler, hipertiroidi, kanama bozukluğu, kontrol altına alınamayan kardiyovasküler hastalığı olanlar ve ozona reaksiyon gösteren astım hastalarında uygulamadan kaçınılmalıdır.

\section{TEDAVI PLANLAMA}

Ozon uygulamalarına ilk bakışta, her hastalıkta kullanılabileceği düşünülse de, aslında tedavi amacına uygun olarak doz ve süresinin planlanması sanıldığı kadar kolay değildir. Yıllarca, ozon uygulamalarının ortodoks 
Tablo 2. Ozon tedavisinin kas iskelet sitemine etkisi

1) Analjezik etki (endorfin salınımı, antinosiseptif sistem aktivasyonu, ödemin azaltılması)

2) Anti-inflamatuvar etki (sitokin salınımının düzenlenmesi, süperoksit radikallerinin azaltılması, prostaglandin modülasyonu)

3) Lokal oksijenasyon ve dolaşımın düzenlenmesi

4) Doku onarımı (preteolitik enzimlerin nötralizasyonu, fibroblast proliferasyonu)

5) Antimikrobik etki

Tablo 3. Ozon tedavisinin temel uygulama teknikleri

1) Majör otohemoterapi: hastadan alınan belli miktarda kanın (genellikle $100 \mathrm{cc}$ ), aynı miktarda ve hedefe yönelik dozda medikal ozon gazı ile en az $5 \mathrm{dk}$ karıştırılması sonrası tekrar intravenöz olarak hastaya verilmesidir.

2) Minör otohemoterapi: $5 \mathrm{~mL}$ kadar kan alındıktan sonra, aynı miktarda ve hedefe yönelik dozda medikal ozon gazı ile karıştıııması sonrasında intramusküler olarak uygulama yapılır.

3) Serum fizyolojik ozonlaması: majör otohemoterapiye alternatif olarak, özellikle Rusya'da tercih edilen ve daha düşük dozların kullanıldığı bir yöntemdir.

4) Gazın direkt uygulamaları: torbalama, kupalama, sauna, intrakaviter-insuflasyon, intramusküler, intradiskal, intra veya peri-lezyonal özel doz ve tekniklerle yapılan uygulamalardır.

5) Ozonlanmış ürünler yoluyla uygulamalar: saf zeytinyağı gibi ürünlerin özel bazı tekniklerle ozonlanması sonrası, genellikle topikal uygulamalarıdır.

tıp tarafından reddedilmesinin nedenlerinden biri de bu düşüncedir. Buna ek olarak, tıbbi ozon uygulayıcılarının, bu bilimsel tedavi yönteminin neden sınırı kaldığı ile ilgili olarak birkaç öngörüsü de vardır ${ }^{[4-8]}$;

1) Gazın, fiziksel, kimyasal ve biyolojik özelliklerindeki belirsizlikler ile birlikte, ilaç endüstrisinin maddi desteğinin olmaması nedeniyle bu konu çok az çalışılmıştır.

2) Terapötik planlar, objektif parametrelerin değerlendirilmesinden ziyade kişisel uygulamalar üzerinde geliştirilmiştir.

3) Klinik deneyim çok iyi olmasına rağmen, özel uygulamayla sınırı kalmış ve sonuçlar hakemli dergilerde yayımlanmamıştır.

"Önce zarar verme" özdeyişi biz hekimlerin birincil prensibi olduğundan dolayı, daha uzun yıllar bu tartışmalar devam edecektir. Öte yandan, tıpkı bir ilaç dozunu ve uygulama yolunu belirler gibi ozonun da optimal doz ve sürede en uygun yolla verilmesine karar vermek, yine bunun eğitimini almış ve kendi uzmanlık alanında doğru uygulamaları benimsemiş hekimin görevidir.

Ozonun doz-etki ilişkisi değerlendirildiğinde temel olarak; düşük dozda stimüle edici etki, orta dozda modüle edici etki, yüksel dozda da inhibe edici etkilerden bahsetmek uygun olur. Bu üç seviyede dozlar belirlenirken, uygulama yolları ve uygulama bölgelerine göre dozlar değişecektir. Kronik hastalıkların temelinde yatan hipoksi ve toksisite; hastaların yakınmaları lokalize edilebilse dahi, ozon tedavisinin bütüncül yaklaşımla ve iyi bir anamnez alınarak sistemik tedavi yollarını da içermesi için önemli bir neden olarak kabul edilir. Bu noktadaki uygulamalar da, majör otohemoterapi, SF, rektal insuflasyon ve sauna uygulamalarını kapsar. Avrupa kaynaklı jeneratörlerde terapötik aralık 1-80 $\mu \mathrm{g} / \mathrm{mL}$ iken, Rus yapımı cihazlarla yapılabilen SF uygulamalarında bu aralık 0-10 $\mu \mathrm{g} / \mathrm{mL}$ 'dir. Lokal uygulamalarda, tedavi bölgesine göre değişmekle birlikte, dozlar genellikle $20 \mu \mathrm{g} / \mathrm{mL}^{\prime} y i$ aşmaz. Kas iskelet sistemi problemlerinde eklem çevresi veya eklem içi uygulamalar, fiziksel tıp, rehabilitasyon ve ortopedi uzmanlarının günlük pratik uygulamalarından çok farklı değildir. Sadece tedavi hedeflerine yönelik doz planlamalarının yapılması uygun olacaktır.

Jeneratörden elde edilen ozon konsantrasyonu $\mu \mathrm{g} /$ $\mathrm{mL}$ (gama) olarak ifade edilirken, bunun mililitre cinsinden verilen hacim ile çarpılması total dozu belirler (Şekil 2). Sistemik uygulama haftada 2-3 kez yapılabilir. Sekiz ila on iki seans uygulamadan sonra, daha uzun aralıklarla kür tekrarı yapılabilir. Minör uygulama genellikle, ilk haftalardaki majör uygulamalar arasında kas içi küçük hacimli hematomlar (en fazla 7-10 cc) oluşturma suretiyle yapılır. Lokal uygulamalarda, yine büyük hacimlerden kaçınmak ve özellikle tek noktada 10-20 cc'yi geçmemek uygun olur. ${ }^{[2]}$

\section{Osteoartritte Ozon Tedavisi}

Osteoartrit; kıkırdak harabiyeti, ağrı, eklem sertliği ve hareketlerde azalma, ilerleyen evrelerde deformiteler ile karakterize, dejeneratif eklem 


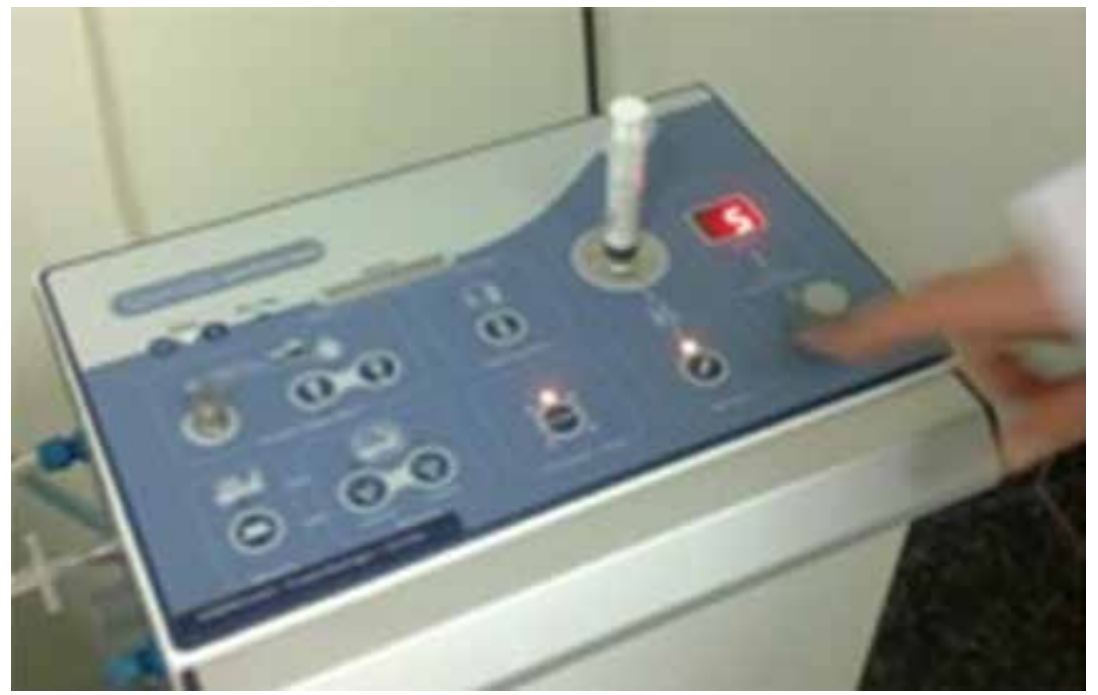

Şekil 2. Ozon dozunun ayarlanması.

hastalığıdır. Hastalığın tedavisinde son yıllarda, intraartiküler ozon enjeksiyonu kullanılmaya başlanmıştır. Neoanjiyogenez sonrası oksijenizasyonda artış, anti-inflamatuvar özellikleri ve antinosiseptif sistem stimülasyonu ile sağladığı analjezik etkisi ile, ozon osteoartit tedavisinde yer bulmuştur. ${ }^{[9]}$ Sinoviya dokuyu stimüle ederek, lubrikasyonu arttırdığı ve kıkırdak tamirini desteklediği belirtilmektedir. Eklem içi vasküler yapılardaki kompresyonu ve stazı azaltarak mikro-sirkülasyonu arttırmakta, böylece oksijenizasyon sağlamakta ve nöronal hipoksiye bağlı ortaya çıkan ağrıyı azaltmaktadır. ${ }^{[10]}$ Ozonun eklem içinde anti-inflamatuvar etkinliği ise, pro-inflamatuvar prostaglandin sentezini baskılaması, bradikinin salınımını inhibe etmesi ve pro-inflamatuvar sitokin antagonistleri salınımını arttırmasına bağlı ortaya çıkmaktadır. ${ }^{[11]}$

Eklem içi ozon uygulamalarının, düşük yan etki profili ile, kısa süreli ağrıda rahatlama sağladığı gösterilmiştir. En sık diz, kalça ve omuz olmak üzere, dirsek, el bileği ve ayak bileği eklem osteoartritinin tedavisinde kullanılabilir. Tıbbi ozonla yapılmış olan randomize kontrollü çalışma çok az olduğundan, tedavi sonuçlarına ilişkin genel çıkarımlarda bulunmak henüz oldukça zordur. Mevcut kinik çalışmalarda, eklem ve omurga osteoartiritinde ozon tedavisi sonrası ağrıda rahatlama sağladığı iddia edilmektedir. ${ }^{[12]}$ Uygulanacak ozon gazı dozu, gaz hacmi, seans sayısı ve sıklığı konusunda bir görüş birliği henüz yoktur. Ancak, en sık uygulama bölgesi olan diz eklemi için $10 \mu \mathrm{g} / \mathrm{mL}$ ve $10 \mathrm{~mL}$ ozon gazının, haftada bir 3-6 seans intra-artiküler enjeksiyonu, yazarın kliniğinde en çok tecrübe edilen uygulamadır. Bununla beraber literatüre bakıldığında, büyük eklemler için $10-20 \mu \mathrm{g} / \mathrm{mL}$ ve $5-20 \mathrm{~mL}$ ozon gazı ve küçük eklemler için aynı dozlarda 1-2 mL haftalık enjeksiyonlar uygulanabilir. ${ }^{[13]}$ Periartiküler ozon uygulaması, sıklıkla intra-artiküler enjeksiyon ile birlikte yapılmaktadır. Örneğin diz osteoartritinde, eklem çevresindeki bursit, tendinit ve entezitlere yönelik $5 \mu \mathrm{g} / \mathrm{mL}$ ve $5-10 \mathrm{~mL}$ ozon gazı verilebilir. Özellikle kronik osteoartrit ağrısının varlığında, kronik ağrı mekanizmasına ve hastanın içinde bulunduğu yorgunluk ve bıkkınlık semptomlarına yönelik sistemik majör otohemoterapi uygulaması da, seanslarda lokal eklem enjeksiyonlarına ek olarak tercih edilebilir.

İntra-artiküler ozon enjeksiyonu, osteoartrit dışında, femur başı avasküler nekrozunda da kullanılabilir. Ultrasonografi (US) ya da floroskopi altında kalça eklemine yönelik yanıta göre, 5-10 kez haftada bir tekrarlayan enjeksiyonların yararlı olduğu olgu bazında gösterilmiştir. ${ }^{[14]}$ Bu durumda $40 \mu \mathrm{g} / \mathrm{mL}$ ve $5 \mathrm{~mL}$ ozon gazı tercih edilebilir. Gaz hacmi yüksek tutulduğunda enjeksiyonun ağrılı olabileceği akılda tutulmalıdır.

\section{Periferik Tendon, Bağ, Kas ve Yumuşak Doku Patolojilerinde Ozon Tedavisi}

Aşııı kullanıma bağlı spor yaralanmalarında; ozon gazı kas içine, tendon çevresine ve bağ dokusunda lezyon içine enjekte edilebilir. Miyofasyal ağrı sendromunda tetik nokta enjeksiyonu, paravertebral kas içi uygulama, lateral epikondilit, Aşil tendinit, subakromiyal ve trokanterik bursit enjeksiyonları, yumuşak doku patolojilerinde en sık ozon uygulamalarıdır. Bu uygulamalarda, ozonun anti-inflamatuvar, analjezik ve stimülan etkilerinden yararlanılmaktadır. Kas içi uygulamanın 
etkinliği şöyle açıklanmaktadır: talamus ve kortekse giden stimülan sinyalleri bloke eden endorfin salınımı, C-nosiseptörlerin oksidatif dejenerasyonuna bağı daha az uyarılması, desandan antinosiseptif sistemin aktivasyonu, lokalize oksijenizasyon ve analjezi sonucunda laktat oksidasyonu, asidozun nötralizasyonu, kalsiyum geri alınımı, adenozin-trifosfat (ATP) sentezinde artış ve ödem reabsorpsiyonu ile kasta gevşeme ve vazodilatasyon sağlanması. ${ }^{[1]}$ Tetik nokta enjeksiyonlarında, cilt altına $5 \mu \mathrm{g} / \mathrm{mL}$ ve $2-3 \mathrm{~mL}$, lezyon içine ise $10 \mu \mathrm{g} / \mathrm{mL}$ ve $2-3 \mathrm{~mL}$ ozon gazı enjekte edilebilir. Paravertebral kas içi uygulamalarda ise $10 \mu \mathrm{g} / \mathrm{mL}$ ve 5-10 mL ozon uygulamaları yapılabilir.

\section{Prolozon}

Son zamanlarda, rejeneratif tedavilerden olan proloterapi ile ozon terapinin kombinasyonundan oluşan prolozon uygulamaları, yumuşak doku lezyonlarında kullanıma girmiştir. ${ }^{[15]} \mathrm{Bu}$ kombinasyonda, ozonun bilinen etkilerine ek olarak, yüksek doz ozon enjeksiyonu ile kronik inflamasyonda rejenerasyonun artışı hedeflenmektedir. Lateral epikondilit tedavisinde 5 $\mu \mathrm{g} / \mathrm{mL}$ ve 3-5 $\mathrm{mL}$ ozon lezyon çevresine uygulanırken, lezyon bölgesinde en hassas noktaya 60-80 mikrog$\mathrm{ram} /$ mililitre dozunda ve iğneleme tarzında prolozon uygulanabilir.

\section{Spinal Ağrılarda Ozon Tedavisi}

Bel ve boyun diskopatilerine bağı ığrılarda, intradiskal ve peridiskal ozon enjeksiyonları uygulanabilmektedir. ${ }^{[16]}$ Disk hernilerinde ozon tedavisi ile, nükleus pulpozus yapısında yer alan proteoglikan yapı okside olur, herni çevresinde hücre metabolizması artar, diskte kemodenervasyon meydana gelerek fitık hacmi küçülür. Diskin içinde, suda hızı şekilde rezorbe olan ozon karbonhidrat, aminoasit ve proteoglikanlar ile reaksiyona girerek dejenerasyon sağlar, hidrolitik ürünlerin ve suyun rezorpsiyonu ile, diskte büzülme meydana gelir. ${ }^{[17]} \mathrm{Bu}$, vertebral sinirler üzerinde analjezik etki gösterir. Tek doz veya gerekirse birkaç doz uygulanabilir. Uygulama, ameliyathane şartlarında floroskopi ve bilgisayarlı tomografi eşliğinde yapılmaktadır. Ozon, tek başına uygulanabileceği gibi kortikosteroid ve lokal anestezikler ile birlikte de uygulanabilmektedir. Intradiskal ozon, konservatif tedaviye dirençlidir ve operasyon düşünülen disk hernisi hastalarında tedavi alternatifi oluşturmaktadır. Ozon gazının dozu 25-40 $\mu \mathrm{g} / \mathrm{mL}$ olarak düzenlenebilir. Lomber disk uygulamalarında 5-10 mL, servikal disk uygulamarında ise $2-3 \mathrm{~mL}$ hacminde ozon gazı kullanılabilir. Radiküler bel ağrısı bulunan hastalarda yapılan klinik çalışmalarda, steroid ile beraber ya da tek başına ozon uygulaması sonucunda, hem bel ağrısı düzeylerinde hem de fonksiyonel

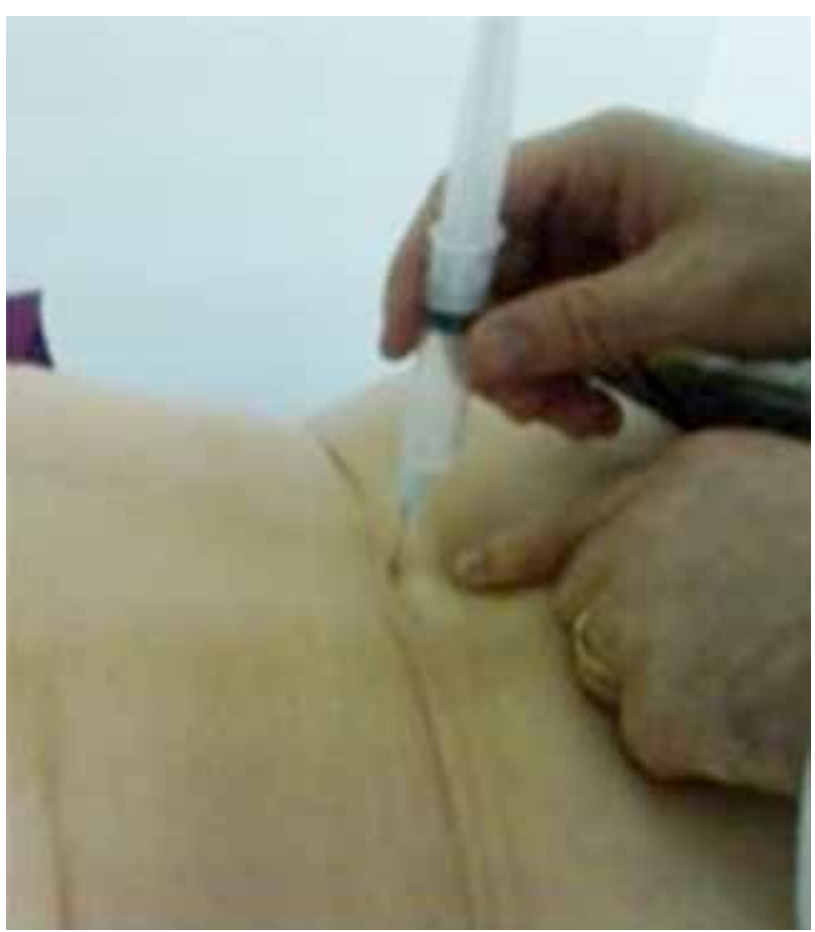

Şekil 3. Lomber periforaminal ozon enjeksiyonu.

olarak anlamlı iyileşme gösterilmiştir. ${ }^{[16,18]}$ İntradiskal enjeksiyon dışında, spinal sinir kökünün hedeflendiği periforaminal enjeksiyonlar da mevcuttur. US eşliğinde yapılabilen periforaminal enjeksiyonlarda, spinöz proçes hattına $2 \mathrm{~cm}$ lateralden girilerek, iğne hafif mediyale doğru ilerletilir (Şekil 3). Ozon gazı $10 \mu \mathrm{g} / \mathrm{mL}$ dozunda ve $5 \mathrm{~mL}$ hacimde tercih edilebilir. Kronik bel ağrısının tedavisinde, başarısız bel cerrahisi sendromu sonrasında lomber bölgede, bilateral üç seviyeden toplam altı enjeksiyon şeklinde ozon tedavisi uygulanabilir.

\section{Kronik (İyileşmeyen) Yaralarda Ozon Tedavisi}

Ozon tedavisi, iyileşmeyen kronik yaralarda ve cilt lezyonlarında yararlıdır. Duyu kaybı olan hastalarda daha sık görülen bası yaralarında ve ampüte hastalarda soket uygunsuzluğu nedeniyle protez vurmasına bağlı ortaya çıkan güdük ucu yaralarında başarıyla kullanılabilir. ${ }^{[19]}$ Ozon tedavisi ile, hem arteriyel hem de venöz mikro-sirkülasyonda düzelme meydana gelir. Ozon, eritrositlerin elastikiyetinde artış meydana getirerek, kapiller alanda doku geçişine daha fazla imkan verir ve doku oksijenizasyonunda artışa yol açar. Peroksitler aracılığıyla DNA üzerinden çoğalmayı sağlar, ATP üretimini arttırır ve hücre rejenerasyonunu tetikler. ${ }^{[9]}$ Ozon gazının antimikrobiyal etkinliği, enfekte yaralarda da yararlı olmasını sağlar. ${ }^{[20]}$ Diyabetik ayak ülserinde, 61 olgu üzerinde yapılan çalışmada, 

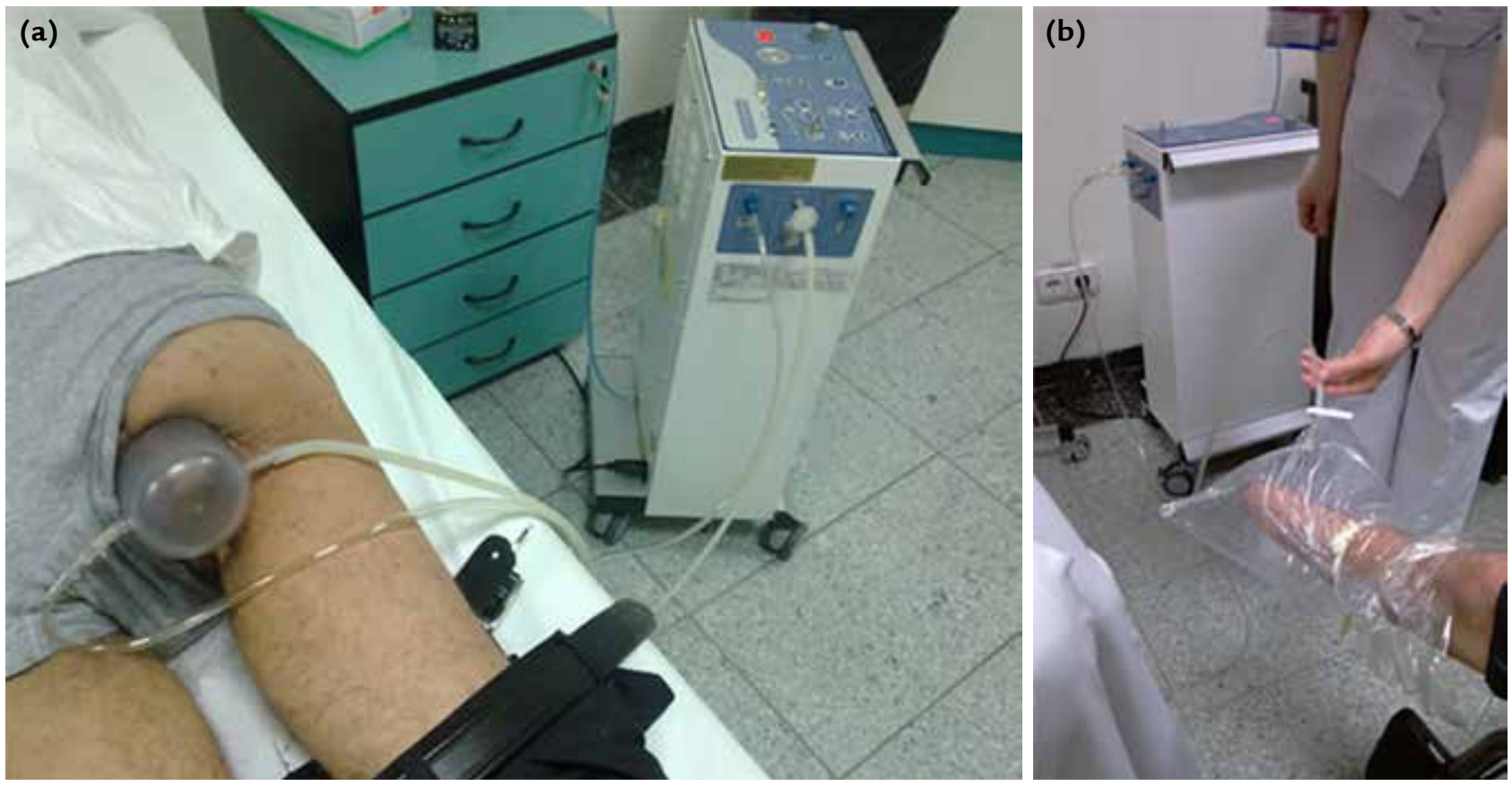

Şekil 4. a, b. Kupa (a) ve torbalama (b) yöntemi ile ozon uygulaması.

konvansiyonel tedaviye adjuvan olarak uygulanan ozon tedavisi ile, plasebo grubuna göre yara kapanmasında daha yüksek orana ulaşıldığı bildirilmiştir. ${ }^{[21]}$ Yaranın boyutuna göre ozon uygulama şekli farklılık gösterebilir. Küçük cilt alanlarında, kupa yöntemi ile düşük basınçlı ozon gazı uygulanır. Bir kupa aracılığıyla, bir hortumdan ozon verilirken, diğerinden ozon cihaza geri alınır. Alt ekstremite yaralarında ise daha ziyade tek uzvu kaplayarak, kapalı devre içerisinde doğrudan gazın cilde temasını sağlayan torbalama yöntemi kullanılır. Ekstremite bir torbanın içine alınır; torbanın içindeki hava vakumlanır; içeriye tıbbi ozon verilir; 20 dk kadar beklenir. Daha sonra ozon cihaza geri alınır. Lezyonun aşamasına ve gelişimine göre, 5-30 dk'lık (torba dolduktan sonar 20-30 dk) dönemlerde 6040-30-20 $\mu \mathrm{g} / \mathrm{mL}$ konsantrasyonları kullanılır. Pürülan enfeksiyonlarda sadece $60-70 \mu \mathrm{g} / \mathrm{mL}$ kullanılabilir. Enfeksion var ise doz azaltılarak, yok ise doz dereceli olarak arttırılarak uygulanmalıdır. Uygulama öncesi cildin hafif ıslatılması önemlidir; nemlendirme ile, ozon gazının cilde daha fazla nüfuz etmesi sağlanır (Şekil 4).

\section{SONUÇ}

Ozon, uzun zamandır tıp alanında bilinirliği olan ve birçok fizikokimyasal özellikleri ortaya konmuş bir moleküldür. Bununla beraber, tedavide kullanımı klinik pratikte daha geç yaygınlaşma eğilimindedir. Elde edilmesi ve tekrarlanması kolay bir tedavi metodu olarak, kas iskelet sistemi hastalıklarında geniş bir kullanım alanı mevcuttur. Kullanıcı eğitimi ve tecrübesi, uygun doz ve uygulama tekniğinin seçiminde önem arz etmekte ve tedavide başarı şansını arttırabilmektedir. Literatürde kısıtlı sayıda klinik çalışma mevcuttur. Kanıt değeri yüksek bilimsel verilerin artması, ozon tedavisinin kullanım standartlarının oluşmasına katkıda bulunacak ve kas iskelet sistemi hastalıklarıyla ilgili hekim grubunun günlük pratiğine daha çok girmesini sağlayacaktır.

\section{KAYNAKLAR}

1. Viebahn-Hänsler R, León Fernández OS, Fahmy Z. Ozone in Medicine: The Low-Dose Ozone Concept -Guidelines and Treatment Strategies. Ozone Sci Eng 2012;34(6):408-24. Crossref

2. Bocci V. Ozone; A New Medical Drug, 2nd ed. Dordrecht Heildelberg New York: Springer Science+Business Media B. V.; 2011. Crossref

3. Masennikov OV, Kontorshchikova CN, Gribkova IA. Ozone Therapy in Practice; Health Manual. Nizhny Novgorod (Russia); 2008. Available from: http://www.absoluteozone. com/assets/ozone_therapy_in_practice.pdf

4. Zanardi I, Borrelli E, Valacchi G, Travagli V, Bocci V. Ozone: A Multifaceted Molecule with Unexpected Therapeutic Activity. Curr Med Chem 2016;23(4):304-14.

5. Bocci V, Borrelli E, Zanardi I, Travagli V. The usefulness of ozone treatment in spinal pain. Drug Des Devel Ther 2015;9:2677-85. Crossref 
6. Bocci V, Borrelli E, Travagli V, Zanardi I. The ozone paradox: ozone is a strong oxidant as well as a medical drug. Med Res $\operatorname{Rev} 2009 ; 29(4): 646-82$. Crossref

7. Bocci VA. Scientific and medical aspects of ozone therapy. State of the art. Arch Med Res 2006;37(4):425-35. Crossref

8. Bocci V. Biological and clinical effects of ozone. Has ozone therapy a future in medicine? $\mathrm{Br} J$ Biomed Sci 1999;56(4):270-9.

9. Bocci V. Oxygen-Ozone Therapy: A Critical Evaluation, 1st ed. Dordrecht: Springer Science+Business Media B. V.; 2002.

10. Shallenberger F. Prolozone $\mathrm{T}^{\mathrm{TM}}$-Regenerating Joints and Eliminating Pain. Journal of Prolotherapy 2011;3(2):630-8.

11. Elvis AM, Ekta JS. Ozone therapy: A clinical review. J Nat Sci Biol Med 2011;2(1):66-70. Crossref

12. Giombini A, Menotti F, Di Cesare A, Giovannangeli F, Rizzo M, Moffa S, Martinelli F. Comparison between intrarticular injection of hyaluronic acid, oxygen ozone, and the combination of both in the treatment of knee osteoarthrosis. J Biol Regul Homeost Agents 2016;30(2):621-5.

13. Johansson E, Claesson R, van Dijken JW. Antibacterial effect of ozone on cariogenic bacterial species. J Dent 2009;37(6):449-53. Crossref

14. Al-Jaziri AA, Mahmoodi SM. Painkilling effect of ozoneoxygen injection on spine and joint osteoarthritis. Saudi Med J 2008;29(4):553-7.
15. Iliakis E, Bonetti M, Iliakis A. Osteonecrosis of the Femoral Head: Could oxygen-ozone therapy became a treatment option? J Ozone Therapy 2015;1(1):1-8.

16. Andreula CF, Simonetti L, De Santis F, Agati R, Ricci R, Leonardi M. Minimally invasive oxygen-ozone therapy for lumbar disk herniation. AJNR Am J Neuroradiol 2003;24(5):996-1000.

17. Korkut $\mathrm{Y}$, Ayada C, Toru Ü. Ozon tedavisi ve servikal lomber disk hernileri üzerine etkisi. Ank Med J 2015;15:161-8. Crossref

18. Zhang $Y, M a Y$, Jiang J, Ding $T$, Wang J. Treatment of the lumbar disc herniation with intradiscal and intraforaminal injection of oxygen-ozone. J Back Musculoskelet Rehabil 2013;26(3):317-22. Crossref

19. Degli Agosti I, Ginelli E, Mazzacane B, Peroni G, Bianco S, Guerriero F, Ricevuti G, Perna S, Rondanelli M. Effectiveness of a Short-Term Treatment of Oxygen-Ozone Therapy into Healing in a Posttraumatic Wound. Case Rep Med 2016;2016:9528572. Crossref

20. Borges GÁ, Elias ST, da Silva SM, Magalhães PO, Macedo SB, Ribeiro AP, Guerra EN. In vitro evaluation of wound healing and antimicrobial potential of ozone therapy. J Craniomaxillofac Surg 2017;45(3):364-70. Crossref

21. Wainstein J, Feldbrin Z, Boaz M, Harman-Boehm I. Efficacy of ozone-oxygen therapy for the treatment of diabetic foot ulcers. Diabetes Technol Ther 2011;13(12):1255-60. Crossref 